\title{
Optimization of Surface Roughness of Bearing Steel during CNC Hard Turning Process
}

\author{
Rony Mohan ${ }^{\# 1}$, Josephkunju Paul C ${ }^{* 2}$, George Mathew ${ }^{\# 3}$ \\ ${ }^{\# 1}$ PG Scholar, Mechanical Engineering Department, Mar Athanasius College of Engineering, Kothamangalam, India \\ ${ }^{* 2}$ Professor, Mechanical Engineering Department, Mar Athanasius College of Engineering, Kothamangalam, India \\ \#3 Assistant professor, Mechanical Engineering Department, Mar Athanasius College of Engineering, Kothamangalam, India
}

\begin{abstract}
AISI $\mathbf{5 2 1 0 0}$ is mainly used to manufacture bearings. The process for manufacturing bearing includes turning process followed by three different stages of grinding operation. Nowadays grinding operation are replaced by hard turning process and it has been proved that hard turning process are $30 \%$ cost effective. The machining parameters (cutting speed, feed rate, depth of cut) are optimized with considerations of surface roughness. Taguchi's concepts of orthogonal arrays, signal to noise $(\mathrm{S} / \mathrm{N})$ ratio and ANOVA are used to optimize the surface roughness for high speed CNC turning process.
\end{abstract}

Keywords- CNC hard turning, surface roughness, AISI 52100, Taguchi, ANOVA.

\section{Introduction}

The hard turning process is superior to grinding in terms of flexibility, ability to achieve higher material removal rates, possibility to operate without coolants etc [1]. For the above mentioned reasons hard turning is replacing grinding operations in industrial applications. AISI 52100 steel alloy also known as bearing steel is mainly used for manufacturing bearings and are well known for their hardness and toughness. They are always available in pre-hardened form.

The aim or objective of this work is to optimize the process parameters such as speed, feed and depth of cut and to investigate the effect of these input parameters on surface roughness. Then to achieve the surface roughness within the rejection criteria $(1.6 \mu \mathrm{m})$ when grinding operation is replaced by $\mathrm{CNC}$ high speed hard turning operation.

\section{High Speed CNC Hard Turning Process}

\section{A. Process Parameters}

The main process parameters selected for the work are speed $(\mathrm{m} / \mathrm{min})$, feed $(\mathrm{mm} / \mathrm{rev})$ and depth of cut $(\mathrm{mm})$. The process parameters and their levels are shown in the Table 1.

\section{B. Workpiece Material}

The workpiece material selected for the work is AISI 52100 bearing steel alloy. It is mainly used to manufacture bearings especially aerospace and automobile bearings. It is always available in prehardened form hence no heat treatments are required. It is delivered fully quenched and tempered to approximately between 700 to $900 \mathrm{HV}$.

\section{Tool Material}

The tool material selected for this work was tungsten carbide tool insert of 0.80 nose radius. The ISO coding is WNMG 120408.

\section{Experimental Setup}

The experimental work was carried out at Center for Research in Design and Manufacturing (CRDM), Karunya institute of technology and sciences under the university of Karunya. The design of experiments was done by making use of Taguchi's method and optimization was done by making use of Fuzzy logic unit. AISI 52100 bearing steel round bar of $25 \mathrm{~mm}$ diameter and $50 \mathrm{~mm}$ length was selected for this work.

The design of experiments are done using Taguhi's L9 orthogonal array and is shown in Table 2. The experimental design proposed by Taguchi involves using orthogonal arrays to organize the parameters affecting the process and the levels at which they should be varies. Instead of having to test all possible combinations like the factorial design, the Taguchi method tests pairs of combinations. This allows for the collection of the necessary data to determine which factors most affect product quality with a minimum amount of experimentation, thus saving time and resources.

TABLE I

PROCESS PARAMETERS AND THEIR LEVELS

\begin{tabular}{|c|c|c|c|}
\hline $\begin{array}{c}\text { Process } \\
\text { parameters }\end{array}$ & Level 1 & Level 2 & Level 3 \\
\hline Speed(m/min) & 120 & 160 & 200 \\
\hline Feed (mm/rev) & 0.10 & 0.12 & 0.14 \\
\hline $\begin{array}{c}\text { Depth of } \\
\text { cut(mm) }\end{array}$ & 0.20 & 0.35 & 0.50 \\
\hline
\end{tabular}


TABLE 2

LAYOUT USING L9 ORTHOGONAL ARRAY

\begin{tabular}{|c|c|c|c|}
\hline Experiment & $\begin{array}{c}\text { Speed } \\
(\mathbf{m} / \mathbf{m i n})\end{array}$ & $\begin{array}{c}\text { Feed } \\
(\mathbf{m m} / \mathbf{r e v})\end{array}$ & $\begin{array}{c}\text { Depth } \\
(\mathbf{m m})\end{array}$ \\
\hline 1 & 120 & 0.10 & 0.20 \\
\hline 2 & 120 & 0.12 & 0.35 \\
\hline 3 & 120 & 0.14 & 0.50 \\
\hline 4 & 160 & 0.10 & 0.35 \\
\hline 5 & 160 & 0.12 & 0.50 \\
\hline 6 & 160 & 0.14 & 0.20 \\
\hline 7 & 200 & 0.10 & 0.50 \\
\hline 8 & 200 & 0.12 & 0.20 \\
\hline 9 & 200 & 0.14 & 0.35 \\
\hline
\end{tabular}

\section{OPtimiZATION OF CNC TURNING PARAMETERS}

\section{A. Signal To Noise Ratio}

There are mainly three categories of performance characteristics

- Lower the better

- Nominal the better

- Higher the better

For 'lower the better' type of machining quality characteristic the $\mathrm{S} / \mathrm{N}$ ratio will be

$\mathrm{S} / \mathrm{N}=-10 * \log \left[1 / \mathrm{n} *\left(\mathrm{y}_{1}{ }^{2}+\mathrm{y}_{2}{ }^{2}+\ldots \ldots+\mathrm{y}_{\mathrm{n}}{ }^{2}\right)\right]$

For 'nominal the better' type of machining quality characteristic the $\mathrm{S} / \mathrm{N}$ ratio will be

$\mathrm{S} / \mathrm{N}=10 * \log \left[\frac{\mu^{2}}{\sigma^{2}}\right]$

For 'higher the better' type of machining quality characteristic the $\mathrm{S} / \mathrm{N}$ ratio will be

$\mathrm{S} / \mathrm{N}=-10 * \log \left[1 / \mathrm{n} *\left(1 / \mathrm{y}_{1}{ }^{2}+1 / \mathrm{y}_{2}{ }^{2}+\ldots . . .+1 / \mathrm{y}_{\mathrm{n}}{ }^{2}\right)\right]$

Here for surface roughness, machining time and tool wear we use lower the better type and for material removal rate we use higher the better type. Here $\mathrm{y}_{1}, \mathrm{y}_{2}, \mathrm{y}_{\mathrm{n}}$ etc. are the measured values and $\mathrm{n}$ is the number of replications or trials performed.

\section{B. Single Character Optimization}

When a single-response problem is considered, Taguchi method and analysis of variance (ANOVA) can be employed to obtain the optimal level/factor combination of high speed $\mathrm{CNC}$ turning process. In the past a lot of researchers studied the effect of various machining parameters in optimizing the machined surface integrity using Taguchi's method. The S/N is used to represent quality characteristic and the largest $\mathrm{S} / \mathrm{N}$ ratio is demanded. In addition, the contribution of each factor is evaluated using the ANOVA.

In this thesis work, for surface roughness, machining time and tool wear lower the better type characteristic equation was used to calculate the signal to noise ratio and for material removal rate higher the better type characteristic equation.

The following Table 3 shows the experimentally obtained surface roughness value for three replication of each experiment. The surface roughness of the machined part was measured by making use of surface roughness tester. The model of the tester is SJ 210 which is a MITUTOYO make. Since there are three replications for each experiment, three readings corresponding to three work specimens are taken and the average value is recorded. The three values are then used to find the $\mathrm{S} / \mathrm{N}$ ratio.

TABLE 3

SURFACE ROUGHNESS AND S/N RATIO OF SR

\begin{tabular}{|c|c|c|}
\hline SL.NO & Average Ra & S/N ratio \\
\hline 1 & 0.839 & 1.52 \\
\hline 2 & 1.119 & -0.997 \\
\hline 3 & 1.287 & -2.193 \\
\hline 4 & 1.059 & -.506 \\
\hline 5 & 0.901 & 0.901 \\
\hline 6 & 0.808 & 1.851 \\
\hline 7 & 0.490 & 6.177 \\
\hline 8 & 1.002 & -0.025 \\
\hline 9 & 1.308 & -2.334 \\
\hline
\end{tabular}

The $\mathrm{S} / \mathrm{N}$ equation used here is lower the better type. Then each combinations corresponding to speed, feed and depth of cut for three different levels were taken and the one with highest average were chosen as the best level. Taguchi's method of analysing means of the $\mathrm{S} / \mathrm{N}$ ratio using conceptual approach is used here. The rank indicates the dominant machining parameter. The best combination of input parameters for the best surface roughness is given in the Table 4.

TABLE 4

RESPONSE TABLE FOR SURFACE ROUGHNESS

\begin{tabular}{|l|l|l|l|}
\hline Variables & $\begin{array}{l}\text { Average } \\
\text { level 1 }\end{array}$ & $\begin{array}{l}\text { Average } \\
\text { level 2 }\end{array}$ & $\begin{array}{l}\text { Average } \\
\text { level 3 }\end{array}$ \\
\hline Speed & -0.556 & -0.842 & $\mathbf{1 . 2 7 2}$ \\
\hline Feed & $\mathbf{0 . 8 0 7}$ & -0.040 & -0.892 \\
\hline Depth & 1.115 & -2.866 & $\mathbf{1 . 6 2 8}$ \\
\hline
\end{tabular}


From the table it is evident that the best combination for surface roughness will be speed at level 3, feed at level 1 , depth of cut at level 3. Thus the values for speed, feed and depth of cut when surface roughness alone was considered were $200 \mathrm{~m} / \mathrm{min}, 0.10 \mathrm{~mm} / \mathrm{rev}, 0.20 \mathrm{~mm}$. Thus a factor level combination of $\mathrm{S}_{3}, \mathrm{~F}_{1}, \mathrm{D}_{3}$ was recommended. The results of ANOVA for the $\mathrm{S} / \mathrm{N}$ ratios of the surface roughness are also shown in table 5 . It can be seen that the contribution of factor F to the surface roughness was the largest (32.3\%). Thus, feed was most important factor followed by depth of cut as far as surface roughness is concerned. It is shown in table 5 .

TABLE 5

ANOVA OF S/N RATIO OF SURFACE ROUGHNESS

\begin{tabular}{|c|c|c|c|c|}
\hline Variables & DOF & SS & MS & Contribution \% \\
\hline S & 2 & 5.323 & 2.662 & 9.84 \\
\hline F & 2 & 17.498 & 8.749 & 32.3 \\
\hline D & 2 & 14.450 & 7.225 & 26.7 \\
\hline Error & 2 & 16.811 & 8.405 & 31.1 \\
\hline Total & 8 & 54.083 & 7.617 & 100 \\
\hline
\end{tabular}

\section{CONCLUSIONS}

This paper has presented the use of Taguchi method in optimization of the high speed CNC turning with single performance characteristics. Performance characteristics namely surface roughness can be improved. It can be concluded that the optimization methodology developed in this study is useful in improving single performance characteristics in high speed CNC turning.

The factor/level combination for surface roughness were speed at level three, feed at level one and depth of cut at level three. Thus, feed was the most important factor followed by depth of cut as far as surface roughness was considered. This work clearly shows that feed is the major factor with a contribution of $32.3 \%$ and the surface roughness value lies within the rejection criteria of $1.6 \mu \mathrm{m}$.

\section{ACKNOWLEDGMENT}

I take this opportunity to express my deep sense of gratitude and sincere thanks to all that helped me complete the work successfully. My first and foremost thanks go to the God Almighty who showered his immense blessing on my effort. It gives me immense pleasure to take this opportunity to express my sincere and heartfelt thanks to my internal guide Dr. Josephkunju Paul C, Head of the Department Mechanical Engineering, MACE, for the continual guidance, support and help throughout the entire period of my work. Last but not the least I am grateful to all staff members of MACE for their kind cooperation and help extended during the work.

\section{REFERENCES}

[1] Anderson P. Paiva and Joao Roberto Ferreira (2007), A multivariate hybrid approach applied to AISI 52100 hardened steel turning optimization, Journal of Materials Processing Technology, (189), 1-3.

[2] Aouici H., Mohamed AthmaneYallese, Kamel Chaoui, Tarek Mabrouki and Jean Francois Rigal, (2012), Analysis of surface roughness and cutting force components in hard turning with CBN tool : Prediction model and cutting conditions optimization, Measurement, (45), 344-353.
[3] Attanasio A., D. Umbrello, C. Cappellini, G. Rotella and R. M'Saoubi (2012), Tool wear effects on white and dark layer formation in hard turning of AISI 52100 steel, Wear, (286-287), 98-107.

[4] Bicek. M, F. Dumont, C. Courbon, F. Pusavec, J.Rech and J. Kopac, (2012) Cryogenic machining as an alternative turning process of normalized and hardened AISI 52100 bearing steel, Journal of Materials Processing Technology, (212), 2609-2618.

[5] C. J. Rao, D. Nageswara Rao and P Srihari, (2013), Influence of cutting parameters on cutting force and surface finish in turning operation, International Conference On DESIGN AND MANUFACTURING, Procedia Engineering, (64), 1405-1415.

[6] Dale W. Schwach and Y.B. Guo, (2006) A fundamental study on the impact of surface integrity by hard turning on rolling contact fatigue, International Journalof Fatigue, (28), 1838-1844.

[7] E.O. Ezugwu, (2005), Key improvements in the machining of difficult-to-cut aerospace superalloys, International Journal of Machine Tool and \& Manufacture, (45), 1353-1367.

[8] Fredrik Svahn, AsaKassman-Rudolphi and Erik Wallen, (2003), The influence of surface roughness on friction and wear of machine element coatings, Wear, (254), 1092-1098.

[9] Gupta. A, Hari Singh, and Aman Aggarwal, (2011) Taguchi-fuzzy multi output optimization (MOO) in high speed CNC turning of AISI P-20 tool steel, Expert System with Applications, (38), 6822-6828.

[10] Ilhan Asilturk and Mehmet Cunkas (2011), Modeling and prediction of surface roughness in turning operations using artificial neural network and multiple regression method, Expert Systems with Applications, (38), 5826-5832.

[11] Jouini . N, Philippe Revel, Guillaume THQUENNE and Fabien LEFEB VRE, (2013) Characterization of surfaces obtained by precision hard turning of AISI 52100 in relation to RCF life, $5^{\text {th }}$ Fatigue Design Conference, Procedia Engineering, (66), 793-802.

[12] Luiz Gustavo D. Lopes, Jose Henrique de Freitas Gomes, Andreson Paulo de Paiva, Luiz Fernando Barca, Joao Roberto Ferreria and Pedro Paulo Balestrassi (2013), A multivariate surface roughness modeling and optimization under conditions of uncertainty, Measurement, (46), 25552568.

[13] Meng Liu, Jun-ichiro Takagi and Akira Tsukuda, (2004) Effect of tool nose radius and tool wear on residual stress distribution in hard turning of bearing steel, Journal of Materials Processing Technology, (150), 234-241.

[14] M.Y. Noordin, V.C. Venkatesh, S. Sharif, S. Elting and A. Abdhulla, (2004) Application of response surface methodology in describing the performance of coated carbide tools when turning AISI 1045 steel, Journal of Materials Processing Technology, (145), 46-58.

[15] Pradeep L. Menezes, Kishore and Satish V. Kailas, (2009), Influence of surface texture and roughness parameters on friction and transfer layer formation during sliding of aluminium pin on steel plate, Wear, (267), 1534-1549.

[16] P.G. Benardos and G. C. Vosniakos (2003), Predicting surface roughness in machining: a review, International Journal of Machine Tools \& Manufacture, (43), 833-844.

[17] Ramon QUIZA SARDINAS, REIS Pedro and PAULO DAVIM J., (2006), Multi-objective optimization of cutting parameters for drilling laminate composite materials by using genetic algorithms, Composites Science and Technology, (66), 3083-3088.

[18] Ramon QUIZA SARDINAS, Santana MR and Brindis EA (2005), Genetic algorithm-based multi objective optimization of cutting parameters in turning process, Engineering Applications in Artificial Intelligence, (19), 127133.

[19] Suha Karim Shihaba, Zahid A. Khan, Aas Mohammad and Arshad Noor Siddiquee, (2014), A review of turning of hard steels used in bearing and automotive applications, Production and Manufacturing Research, (2), 24-49.

[20] T.G. Brito, A.P. Paiva, J.R. Ferreira, J. H. F. Jomes and P. P. Balestrassi, 2014, A normal boundary intersection approach to multi response robust optimization of the surface roughness in end milling process with combined arrays, Precision Engineering, (38), 628-638.

[21] Yavuz Sun and Hayrettin Ahlatci, (2011), Mechanical and wear behaviors of $\mathrm{Al}-12 \mathrm{Si}-\mathrm{XMg}$ composites reinforced with in situ $\mathrm{Mg}_{2} \mathrm{Si}$ particles, Materials and Design, (32), 2983-2987. 